\title{
Difficulties for Teleworking of Public Employees in the Spanish Public Administration
}

\author{
José María Ortiz-Lozano ${ }^{1}$ (D) Pedro César Martínez-Morán ${ }^{2, * \mathbb{D}}$ and Iván Fernández-Muñoz ${ }^{3}$ \\ 1 Quantitative Methods Department, Faculty of Economics and Business Administration, \\ Universidad Pontificia Comillas, 28015 Madrid, Spain; jmortiz@comillas.edu \\ 2 Management Department, Faculty of Economics and Business Administration, Universidad Pontificia Comillas, \\ 28015 Madrid, Spain \\ 3 ICADE Business School, Universidad Pontificia Comillas, 28015 Madrid, Spain; \\ ifernamu@alu.comillas.edu.com \\ * Correspondence: pmartinez@comillas.edu
}

Citation: Ortiz-Lozano, J.M.

Martínez-Morán, P.C.;

Fernández-Muñoz, I. Difficulties for Teleworking of Public Employees in the Spanish Public Administration. Sustainability 2021, 13, 8931

https://doi.org/10.3390/su13168931

Academic Editor: Grigorios

L. Kyriakopoulos

Received: 8 July 2021

Accepted: 5 August 2021

Published: 10 August 2021

Publisher's Note: MDPI stays neutral with regard to jurisdictional claims in published maps and institutional affiliations.

Copyright: (c) 2021 by the authors. Licensee MDPI, Basel, Switzerland. This article is an open access article distributed under the terms and conditions of the Creative Commons Attribution (CC BY) license (https:// creativecommons.org/licenses/by/ $4.0 /)$

\begin{abstract}
This paper studies the extent to which difficulties in teleworking continue to be encountered by civil servants of the Spanish General State Administration (AGE) who, after the mandatory lockdown decreed by the Spanish Government from March to May 2020, continue to carry out their work under this modality. The results obtained support that the main difficulties are the acquisition of bad posture and problems in separating work and family life, and the presence of different types of difficulties differs depending on gender, the structure of the household, or whether the employee belongs to the levels of positions where higher qualification is required. In addition, ambiguity is expressed regarding the provision of resources and lack of training provided by the AGE.
\end{abstract}

Keywords: difficulties for teleworking; Spanish public administration; training for teleworking; resources for teleworking

\section{Introduction}

The health crisis caused by COVID-19 has had an impact on all areas of daily life. Organizations and companies have seen their activities altered. Workplaces, methods, and resources have been modified. The pandemic has led to a cataclysm in working conditions unknown in peacetime [1]. 2020 closed with $8.8 \%$ of global hours worked lost relative to the last quarter of 2019 and with $93 \%$ of the global workforce residing in countries with difficulty accessing their jobs [2,3]. Teleworking is emerging as the only alternative to soften the impediment of not being able to go to the physical workplace.

The use of telework in Europe has increased in the last 10 years. Its level of growth has been higher than in Spain [4]. The latest data show that, in 2020, 12.3\% of the working population in the EU-27 usually worked from home [5]. Finland (25.1\%), Luxembourg $(23.1 \%)$, and Ireland $(21.5 \%)$ are at the top of the telework ranking on the European continent. Table 1 provides a comparison between the highest percentage of employed men and women working from home in Europe at the end of 2020.

The implementation and diffusion of this remote work modality at a European level did not begin until the 1990s. The Bangemann Report (1994) identified telework as one of the 10 priority actions to stimulate the development of the information society in Europe [6].

The European Framework Agreement on Telework (2002) aimed to establish a legal framework for telework in Europe [7]. It also seeks to provide greater security for teleworkers in the European Union and establish a general framework for their working conditions [8]. This agreement considers that teleworking could facilitate the modernization of companies and public service organizations, as well as being a means for workers to reconcile professional and personal life and enjoy greater autonomy in the performance of their tasks. 
Table 1. Countries with a higher percentage of employed males and females over the total number of people of the corresponding sex who are between 15 and 64 years old and working from home in 2020 .

\begin{tabular}{ccc}
\hline Country & $\begin{array}{c}\text { Percentage of Employed Men } \\
\text { Who Work from Home }\end{array}$ & $\begin{array}{c}\text { Percentage of Employed Women } \\
\text { Working from Home }\end{array}$ \\
\hline Finland & $24.8 \%$ & $25.5 \%$ \\
Luxembourg & $22.5 \%$ & $23.9 \%$ \\
Ireland & $21.3 \%$ & $21.7 \%$ \\
Spain & $9.9 \%$ & $12.1 \%$ \\
EU-27 average & $11.5 \%$ & $13.2 \%$ \\
\hline
\end{tabular}

Source: Own elaboration based on Eurostat data.

Spain has not been an exception to the labor disruption caused by the pandemic. The percentage of people teleworking in Spain, at the end of 2020, was $10.9 \%$ of its workforce, almost one and a half percentage points below the EU-27 [5]. At the beginning of May 2020, the Spanish working population teleworking peaked at 34\% [9]. The Spanish government gave preference to telework [10] with two royal decrees in March and April 2020, respectively. However, each sector has reacted unevenly, with the size of the companies being one of the determining factors [11]. Public administration is among the sectors with the lowest implementation of telework in Spain.

In Spain, the specific regulation of teleworking can be found through the reform of Article 13 of the Workers' Statute (2015) which is introduced from the Royal Legislative Decree 2/2015 [12]. The most recent legislative development is the Royal Decree Law $28 / 2020$, of September 22 [13], on telecommuting, which insists on the voluntary nature of the measure. Rastrollo [14] considers that the public employee is going to be conditioned by the obligation to telework by virtue of the "good functioning of the public service". Circumstances that condition him against the worker of the private sector.

This research has focused on the Spanish General State Administration (hereinafter, AGE). This institution employs 231,456 civil servants [15,16]. Anghel et al. [4] estimated that $3.1 \%$ of workers attached to the Public Administration, Defense and Social Security had some telework experience and they raised to $34.3 \%$, the number of employees of such services that could telework. Bermúdez and Fuentes [17] add a discouraging shadow: they believe the current model is unsustainable and hypothesize about the future disappearance of one million jobs due to the use of robotics and artificial intelligence.

AGE has been defined since the approval of the Spanish Constitution in 1978. Its task is to execute the administrative policy of the Spanish government. The Basic Statute of Public Employment (2015) regulates the functions of the people working within this body [18]. Articles 75 and 76 of said Statute define the grouping of civil servants into bodies, scales, and specializations. Different levels are assigned to this grouping.

Article 70 of the Reglamento General de Ingreso (hereinafter, RGI) (1995) indicates that positions in the AGE are classified into 30 levels [19]. These levels are grouped into intervals of jobs corresponding to each group or scale according to Article 71.1 of the RGI. The third transitory provision of the Consolidated Text of the Basic Statute of Public Employment (hereinafter, TREBEP) (2020) indicates the minimum and maximum intervals for each classification group. Table 2 lists the different existing groups and the corresponding levels:

Table 2. Groups, positions, and levels of the AGE.

\begin{tabular}{cclll}
\hline Group & Subgroup & \multicolumn{1}{c}{ Occupant Profile } & Type of Position & Levels \\
\hline \multirow{2}{*}{ A } & A1 & $\begin{array}{l}\text { Bachelor's degree, Engineer, Architect } \\
\text { or equivalent }\end{array}$ & $\begin{array}{l}\text { Direction, execution, control, } \\
\text { and study. }\end{array}$ & $\begin{array}{l}\text { Minimum, 20. } \\
\text { Maximum, 30 }\end{array}$ \\
\hline \multirow{2}{*}{ B } & A2 & $\begin{array}{l}\text { Diploma, Technical Engineering, } \\
\text { Technical Architecture or equivalent }\end{array}$ & $\begin{array}{l}\text { Management and collaboration } \\
\text { in administrative functions. }\end{array}$ & $\begin{array}{l}\text { Minimum, 16. } \\
\text { Maximum, 26 }\end{array}$ \\
\hline
\end{tabular}


Table 2. Cont.

\begin{tabular}{cclcc}
\hline Group & Subgroup & \multicolumn{1}{c}{ Occupant Profile } & Type of Position & Levels \\
\hline C & C1 & $\begin{array}{l}\text { High school diploma, intermediate } \\
\text { vocational training or vocational } \\
\text { training technician, high school } \\
\text { diploma, FP2 or equivalent. }\end{array}$ & Administrative body & $\begin{array}{c}\text { Minimum, 11. } \\
\text { Maximum, 22 }\end{array}$ \\
\hline D & C2 & $\begin{array}{l}\text { ESO, school graduate, FP1 or } \\
\text { equivalent }\end{array}$ & Assistant & Minimum, 9. \\
E & & No degree required & Surveillance and custody & Minimum, 7. \\
\hline
\end{tabular}

Source: Prepared by the authors based on Royal Legislative Decree 5/30 October 2015, approving the recast text of the Basic Statute of the Public Employee Law.

AGE also showed interest in teleworking prior to the outbreak of COVID-19. In 2005, the Plan Concilia was approved [20]. It was implemented with the aim of applying teleworking techniques for public employees, and favoring the reconciliation of work, family, and personal life [8]. This led to the publication of Order APU/1981/2006 [21] promoting the implementation of telework pilot programs in several ministerial departments. The declaration for social dialogue in public administrations, signed by the Administration and the main trade unions (UGT, CCOO, and CSI-CSIF), was decisive in introducing telework in the public sector [22] since Spanish public employees lacked any mention of telework, in the consolidated text of the Law of the Basic Statute of the Public Employee (2015).

As a result of the COVID-19 outbreak, a series of measures favoring teleworking were developed and implemented in the AGE. They were agreed upon and signed by the heads of the Administration and labor union representatives, UGT, CSIF, and CIG [15,16]. On 22 June 2020, the resolution on the conditions of the new normality came into force. Additionally, different resolutions have deepened in the previous resolution. The most noteworthy is the inclusion of the regulation of teleworking in public administrations in Article 47 bis of the TREBEP. It establishes its voluntary and reversible nature and the equality of conditions for teleworkers who use it compared to those who work in person.

The difference between the number of people who telework in the AGE in comparison to the rest of the Spanish working population, together with the lack of flexibility of this organization [23], provides the opportunity to analyze the perception of the decisions taken regarding the provision of resources available to workers and to identify the main difficulties encountered.

The contribution of this work is based on pointing out the main difficulties the collective of people of AGE, who have used telework during the pandemic, had to face. In addition, it also highlights the impact that the provision of infrastructure, resources, and training has had on the performance of their job responsibilities.

The structure of the research is broken down as follows: firstly, a review of the literature on the difficulties of teleworking. This is followed by the method of analysis used, both in terms of database management and modeling. Thirdly, the main results of the study are presented. Finally, the main conclusions and future lines of discussion are presented.

\section{Literature Review}

Despite the lack of consensus in its definition, there are common elements in the conceptualization of telework [24]: it takes place outside the company and uses information and communication technologies [25-31]. Their lack of mass extension has been because technology did not allow it [32]. These technologies also generate a relationship of mutual dependence with the work itself [33]. Mokhtarian and Salomon [34] emphasize the lack of discipline generated by the office itself, which in the case of teleworking requires selfcontrol, self-discipline, and organization of one's own work [35] add the lack of control of the workload, a signal that radiates both from the worker and from the management of their area of responsibility. The cost savings pursued to prevent the consequences of the oil 
crisis [36] did not lead to an immediate paradigm shift. In addition, while the advantages of teleworking outweigh its limitations, Beño [37] emphasizes that not all sectors, individuals or professions, can work in this way.

Constraints to teleworking during COVID 19 were concentrated on: having the office at home, job uncertainty and, finally, not having adequate tools. Gender, household structure, age, and position in the organization chart were found to explain the differential impact of working from home on individuals [38]. Mokhtarian et al. [39] analyzed difficulties by occupation and gender, with office workers reporting potential misunderstandings, lack of relationship with the supervisor, or risk aversion as constraints; managers, on the other hand, focusing on less professional relationships and domestic distractions in households with children. Executives and managers are more likely to telework [40], which is confirmed by the estimates of Holgersen et al. [41] in that $66.8 \%$ of managers would be willing to telework or the predictions of Adams-Prassl et al. [42] that place management in a position of prevalence to be considered as a function that can be performed from home, both by type of occupation and by type of industry. From a legal perspective, BelzuneguiEraso and Erro-Garcés [43] concluded that the collective and agreement plans included teleworking only as a solution to home and family needs

The household structure also affects workers with children. Women are constrained by the lack of supervision and visibility for their work and are willing to accept lower wages [44]. Troup and Rose [45] emphasize the different impacts of teleworking on workfamily balance and especially in two areas: job satisfaction and satisfaction with the distribution of childcare tasks.

Increased awareness of work-life balance [46,47] is corrected by the fact that flexible working hours are associated with employment for women [48,49]. The method of work can exacerbate inequality in the household $[50,51]$ and the potential emergence of conflicts between work and family life [52-54], underlining the extreme interaction between the two spheres and the difficulty of separation between them. Gálvez et al. [55] explain that it goes further than a restructuring between these domestic spheres; they are related to both working attitude, personal engagement, and material arrangements. Greater intrusion into non-work areas of life is facilitated [56]. Women witness a multiplication of their working hours and a lack of time for themselves [57], which generates stress and the perverse effect of feeling bad for not getting everything done; moreover, professionally, their opportunities for promotion are reduced [58]. This leads to restrictions in reconciling work and family life and social isolation [59]. Social isolation [60-63], which is associated with the impediment of informal communication and the generation of spontaneous professional relationships [64].

As a consequence of the scarcity of infrastructure and the problems arising from the infrastructure itself, the potential benefits of teleworking are undermined, which makes it more work for the teleworker $[65,66]$.

Additionally, ILO [2,3] highlights the worker's right to receive from his or her employer the equipment and tools necessary for his or her work and access to technologies and tools as if he or she were in the workplace. Scott et al. [67] noted that efficient technology was not enough to achieve a high success rate in the adoption of telework as an option. The decision to telework partially, full time, to use one's own home or another location than the workplace, is complex.

Lack of infrastructure is seen as a disadvantage to work [52-68]. Limón [69] outlines that Peruvian legislation admits that for the execution of telework any means can be used that enables work tasks to be carried out elsewhere than at the workplace, without expressly stating who is responsible for providing adequate resources. Behrens et al. [70] conclude that teleworking is not a successful solution: it reduces the demand for office space but requires more space at home.

Infrastructure is affected by equipment costs. It requires an investment effort on the part of the company [71]. Barandiarán [72] reflects that, in Spain, the only thing established, and ambiguous, is the obligation on the part of companies to provide the necessary resources to workers. Any compensation for expenses is postponed to collective 
bargaining and for the post-pandemic stage, and assuming that telework will be that which exceeds two days of dedication per week or more than $30 \%$ of the working day, an inventory of necessary means and equipment, including consumables and furniture, will have to be elaborated. The company will have to pay for its own equipment. Equipos y Talento $[73,74]$ includes a study by an office furniture company, Fellowes, which quantifies the expenditure made by Spanish teleworkers during the pandemic at 615 euros, mainly invested in: headsets, printers, desks, and chairs with ergonomic backrests. The same study mentions that $12 \%$ of people requested equipment without receiving any response, and another $8 \%$ received a negative response. The same journal, Equipos y Talento [73,74], echoes another study that states that 4 out of 10 teleworkers noted increases in electricity and internet at home.

The physical relocation of the workplace and the use of new tools implies the need to use and apply new knowledge to work remotely. The difficulty stems from the lack of training in the use of digital resources [75] and the lack of specific training is seen as a disadvantage [76,77]. IEBS [78] highlights in its research that three out of four workers consider that they have not received sufficient training to telework and $40 \%$ of workers believe that they are not sufficiently qualified to telework. Baruch [79] focuses training needs for remote working on time management and social contact management, rather than technical skills. Vasic goes beyond [80] because he thinks that if companies invest in teleworking training programs, teleworkers will be more satisfied and will have a higher loyalty.

According to a UK study, home as the new workplace promotes diverse health issues: pain in the back, wrists, knees, and lower back [81]. A weakness of teleworking has been the damage caused by the wrong posture due to inappropriate desks and chairs or screens that are too high [82]. Thus, there is a high cost to health, and it is even assumed to be a primary limitation of teleworking [83]. Besides, mental health can be affected not only by the previous items but also by the lack of space, long-time working hours, isolation, and loneliness. All of these may cause potential mental risks [84].

The negative factors of teleworking concentrate the findings stated by de Vries et al. [47] in their research on public employees in was said that: it leads to greater isolation and less engagement with the organization when working entirely from home. Kwon and Jeon [85] warn about the challenge of the additional costs associated with supervising remote workers in public organizations. It is also taken into account the unforeseen inconveniences of remote working which can diminish teleworker satisfaction.

In addition to Couto's [86] notes, in her research on public employees, that women are the ones who spend more time on household tasks and consider that the mental burden has fallen mostly on them. The article concludes with the fact that people without children find it easier to organize teleworking and have fewer concentration problems. Consequently, a higher percentage of childless workers would like to continue teleworking. Couto [86] also supports that there is a gender difference in the perspective on the effects on one's own work, with men considering it positive to a greater extent than women.

Finally, as we stated before, the COVID-19 has influenced world's daily life and as a consequence the post-COVID-19 city requires reforms. Since the first quarter of 2020, the standard way of living has been disrupted. Modern life does not understand without living in healthy environments. Health policies are needed with action programs that focus on healthier, greener, and more socio-economically balanced places to live $[87,88]$. People should think about positive ways of living together [89]. The pandemic has shown the flaws of a model of coexistence. The barriers and difficulties have not appeared due to the COVID-19. They emerged in the last century, such as pollution [90], and now it is time to minimize and reduce the negative impacts for citizens and going forward to socialize and building community [91]. 


\section{Materials and Methods}

Regarding the difficulties identified for teleworking in the theoretical framework and the objective of determining those most frequently reported by public employees in the AGE, this work was based on a survey carried out from November to December 2020 within the context of the master's degree in Human Resources at Comillas Pontifical University. For the distribution of this survey, the help of two entities linked to the public sector was requested, the Federation of Citizen Services of the FAC-USO trade union and the Association of Women in the Public Sector, in addition to requesting the collaboration of various members of the group studied who are personal contacts of the authors of this work.

The unit of analysis was not each public employee who responded to the survey, but the record of each difficulty reported by public employees who responded to the survey and who indicated that they teleworked at least partially within their normal working day.

Of the total number of public employees who answered the survey, 241 surveys corresponding to those who declared that they teleworked more than two days a week or more than $30 \%$ of the working day are examined in this study, giving a total of 438 records of the difficulties referred to, which make up the sample analyzed. The details of the variables obtained, and their possible responses can be consulted in Table A1, which is presented in the corresponding Appendix A.

The R programming environment [92] was used to manage the database and build the models. Statistical processing was performed using the basic functions included in this programming environment and the packages car [93], dplyr [94], ggplot2 [95], readxl [96], RcmdrMisc [97], and summarytools [98].

Statistically, Levene's tests were used to test the assumption of homoscedasticity of variances and $t$-tests for equality of means and, where appropriate, Welch robust tests for equality of means $[99,100]$. The standard social science confidence level of $95 \%$ was used for the appropriate tests.

The main objective of this paper is to study the frequency of the main difficulties in teleworking that have been identified in the literature for the specific case of public employees in the General State Administration. This was split into two, the study of how they may vary depending on whether the job is a high-level position or on issues related to the personal context of the person. Consequently, based on the theoretical framework and the empirical evidence found in previous studies, the following hypotheses are put forward:

Hypothesis 1 (H1). There are significant differences for teleworking in the difficulties referred to depending on whether the public employee is executive or not.

Hypothesis 2 (H2). There are significant differences for teleworking in the difficulties referred to depending on whether the public employee has children or not.

Hypothesis 3 (H3). There are significant differences in teleworking difficulties according to the gender of the public employee.

Hypothesis 4 (H4). There are significant differences for teleworking in the difficulties reported depending on whether the public employee lives with a partner or not.

\section{Results}

Firstly, it can be seen in Figure 1 that $58 \%$ of the respondents stated that the organization belonging to the Spanish General State Administration in which they work had provided them with the necessary tools to telework. When analyzing the scope of the training required, only $22 \%$ of them stated that they had received training for teleworking from their organization. On the other hand, only $1.7 \%$ of respondents considered that they 
did not have adequate resources for teleworking, compared to $49.8 \%$ who considered that they had all the appropriate resources.
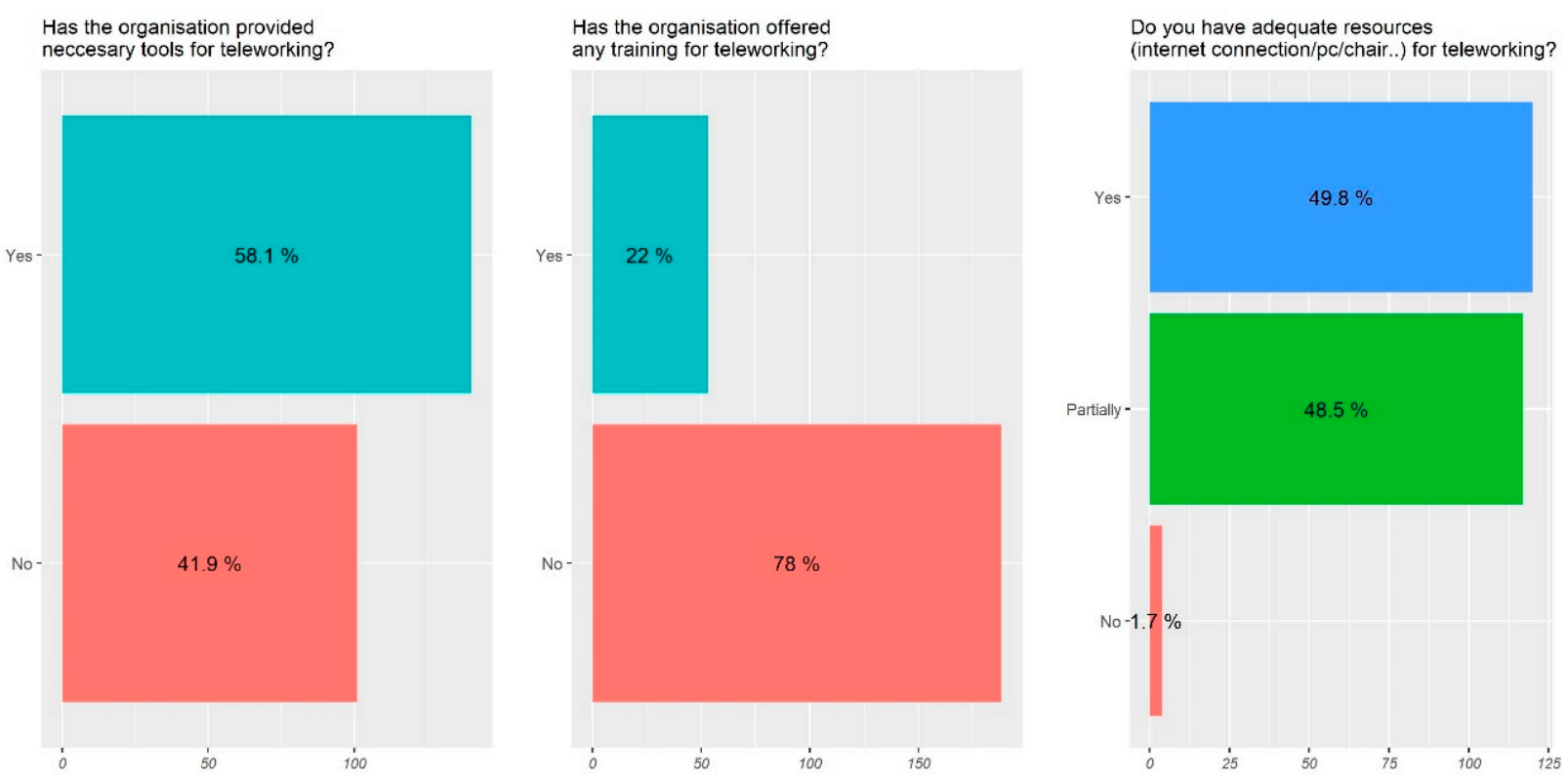

Figure 1. Relative frequency of the analyzed group on resources and tools provided or available to telework.

When we look down to the main objective of this study, as can be seen in Figure 2, we find that only $8.3 \%$ of the respondents stated that they had none of the difficulties they were asked about. Consequently, most respondents do report one or more of the difficulties in teleworking.

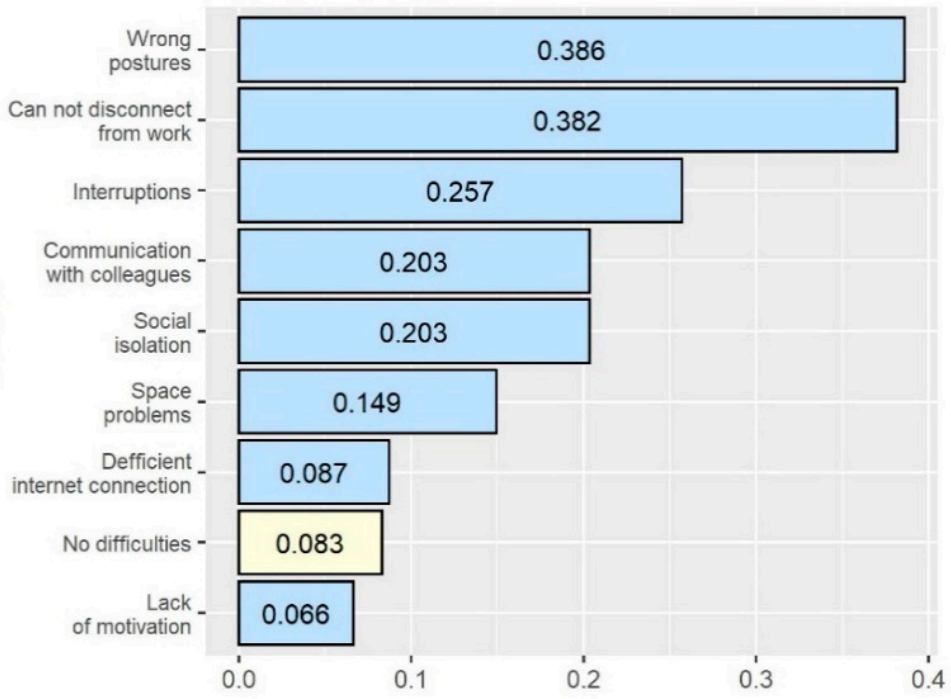

Figure 2. Relative frequency of the difficulties studied in the group analyzed.

The most frequently reported difficulty was wrong postures (38.6\%), followed closely by problems in disconnecting from work (38.2\%) and personal interruptions (25.7\%). On the other hand, the least frequently reported difficulty is lack of motivation $(6.6 \%)$, followed by poor internet connection $(8.7 \%)$.

The results of the different tests carried out can be consulted in Table A2, which is presented in the corresponding Appendix A.

When studying the first hypothesis corresponding to the frequency of the difficulties studied depending on whether the public employee belongs to the highest professional 
level or not (Figure 3), comparable to holding an executive position in other organizations, it can be seen that there are only statistically significant differences in being able to disconnect from work.
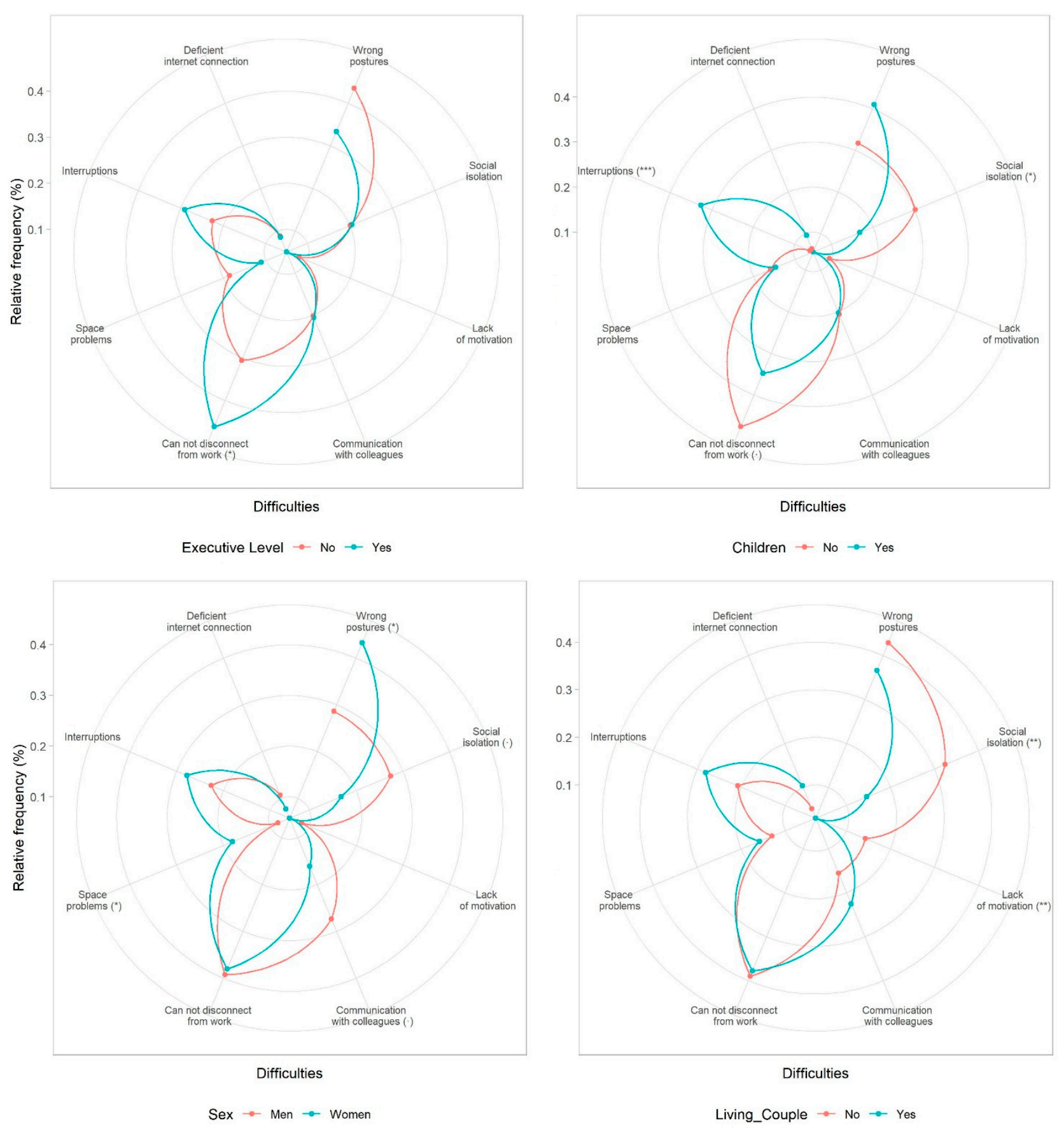

Figure 3. Relative frequencies of difficulties reported by the group analyzed depending on whether they hold an executive role (higher job scales) or not, whether they have children or not, whether they live with a partner or not, and their sex. Significance codes: ${ }^{* * *} 0.001 ;{ }^{* *} 0.01 ;{ }^{*} 0.05 ; \cdot 0.1$.

In addition, when we go down to the personal context of the individual, there is greater heterogeneity in the frequency of the difficulties reported. Thus, in relation to our second hypothesis, the results obtained according to whether the person in the group analyzed has children or not, the difficulty with the greatest difference is the number of interruptions suffered in the case of having children. Next, the feeling of social isolation is another difficulty that emerges differently in the group analyzed, being significantly 
greater in the case of not having children. Likewise, when we study the results linked to our third hypothesis, the differences according to the sex of the person, we can observe that women present a higher frequency than men in the difficulties linked to the acquisition of bad posture and physical space problems.

Finally, in relation to the fourth hypothesis, when the group members studied do not live with a partner, they report a higher frequency of difficulties of social isolation and lack of motivation to telework than those reported by their public service colleagues who do live with a partner. With regard to the difficulty of lack of motivation, the authors consider it interesting to note that, despite being the least frequent difficulty in aggregate terms, it emerges significantly in the case of the person not living with a partner.

\section{Discussion}

The authors have been able to confirm that most of the difficulties identified in the literature are also present in the AGE, although with interesting considerations.

First, the results of this work support the ambiguity pointed out by Barandiarán [72] in relation to the Spanish context regarding the obligation on the part of companies to provide necessary resources to workers for teleworking adequately.

Second, the results of IEBS [78] are also confirmed, given that 3 out of 4 AGE workers who telework report that they have not received enough training. However, despite the above, it is also interesting to note that only a very small percentage say that they do not have adequate means to telework. This suggests that AGE teleworkers have had to finance, in whole or in part, the resources or technological infrastructure required and/or train themselves in order to be able to telework adequately.

Additionally, in relation to the greatest difficulties encountered in teleworking in the AGE, in line with what has been anticipated in general terms by Ballard [81,83], the main difficulty has emerged as the acquisition of wrong postures. Our research also supports that this difficulty is perceived more frequently in the case of women than men.

Furthermore, this study also confirms for the group analyzed the importance of the difficulty of disconnecting from work when teleworking. These results are consistent with those obtained by Dockery and Bawa [56], who anticipated that working under this modality facilitates greater intrusion into non-work areas of life. However, we note that in the group analyzed, our research suggests that this problem is significantly greater in higher-skilled positions.

Moving down to the household structure, the emergence of conflicts between work and family life is confirmed by, among others, Barros and Silva [52], Nohara et al. [54] and da Costa [53]. As Gálvez et al. confirm [55], this potential conflict will need more than a restructuring among the domestic spheres. In this area, among people who live with children, suffering interruptions from the family environment while teleworking has emerged as a major difficulty in carrying out work activities. The authors consider it interesting to note that, in the sample analyzed, suffering interruptions from the family environment occurs with similar frequency in both women and men.

Finally, our results also support that, when teleworking, the feeling of social isolation is encouraged and is a relevant difficulty. While these results are in line with those anticipated by Bartol et al. [59] and Lodovici [84], our work suggests that the structure of the household is a determining factor and that the above-mentioned difficulty is particularly present in people who do not live in a couple.

\section{Conclusions}

The healthcare crisis caused by COVID-19 has led to a paradigm shift in working models, with teleworking making a strong appearance. In this scenario, this paper has studied the frequency of occurrence for the main difficulties in teleworking identified in the literature, within the context of the civil servants of the Spanish General State Administration (AGE) who, after the mandatory lockdown decreed by the Spanish Government from March to May 2020, continue teleworking. 
Although the results obtained should be generalized with caution, given the context and the size of the sample analyzed, this work confirms that teleworking brings important difficulties to deal with. The difficulties for teleworking in the AGE that top the poll are wrong postures, problems in disconnecting, personal interruptions, and communication and isolation problems.

Regarding the perception of teleworking difficulties, this work has confirmed that social and personal context matters. However, although this work has delved into some of them, future research could try to shed some light on studying their interactions.

Finally, the authors consider it relevant to dig deeper into researching the role of civil servants' teleworking in the so-called post-COVID-19 city, including health mental risks and the way of providing better options to balance working and personal life and finding procedures to make cities healthier.

Author Contributions: Conceptualization, P.C.M.-M.; methodology, J.M.O.-L. and P.C.M.-M.; validation, J.M.O.-L. and P.C.M.-M.; formal analysis, J.M.O.-L. and P.C.M.-M.; investigation, J.M.O.-L. and I.F.-M.; data curation, J.M.O.-L. and I.F.-M.; writing-original draft preparation, J.M.O.-L. and P.C.M.-M.; writing-review and editing, J.M.O.-L., P.C.M.-M. and I.F.-M.; visualization, J.M.O.-L.; supervision, J.M.O.-L. and P.C.M.-M. All authors have read and agreed to the published version of the manuscript.

Funding: This research received no external funding.

Institutional Review Board Statement: Not applicable.

Informed Consent Statement: Informed consent was obtained from all subjects involved in the study.

Data Availability Statement: The data presented in this study are available on request from the corresponding author.

Conflicts of Interest: The authors declare no conflict of interest.

\section{Appendix A}

Table A1. Description of the variables collected.

\begin{tabular}{|c|c|c|}
\hline No & Variable & Values \\
\hline \multirow{2}{*}{1} & \multirow{2}{*}{$\begin{array}{l}\text { Has the organization provided any tools for } \\
\text { teleworking? }\end{array}$} & 1. No \\
\hline & & 2. Yes \\
\hline \multirow{2}{*}{2} & \multirow{2}{*}{$\begin{array}{l}\text { Has the organization offered any training for } \\
\text { teleworking? }\end{array}$} & 1. No \\
\hline & & 2. Yes \\
\hline \multirow{3}{*}{3} & \multirow{3}{*}{$\begin{array}{l}\text { Do you have adequate resources (internet } \\
\text { connection/computer/chair ... ) for } \\
\text { teleworking? }\end{array}$} & 1. No \\
\hline & & 2. Partially \\
\hline & & 3. Yes \\
\hline \multirow{2}{*}{4} & \multirow{2}{*}{ Children } & 1. No \\
\hline & & 2. Yes \\
\hline \multirow{2}{*}{5} & \multirow{2}{*}{ Sex } & 1. Men \\
\hline & & 2. Women \\
\hline \multirow{2}{*}{6} & \multirow{2}{*}{ Living_Couple } & 1. No \\
\hline & & 2. Yes \\
\hline \multirow{2}{*}{7} & \multirow{2}{*}{ Executive Level } & 1. No \\
\hline & & 2. Yes \\
\hline
\end{tabular}


Table A1. Cont.

\begin{tabular}{|c|c|c|}
\hline No & Variable & Values \\
\hline \multirow{2}{*}{8} & \multirow{2}{*}{ Wrong postures } & 1. No \\
\hline & & 2. Yes \\
\hline \multirow{2}{*}{9} & \multirow{2}{*}{ Social isolation } & 1. No \\
\hline & & 2. Yes \\
\hline \multirow{2}{*}{10} & \multirow{2}{*}{ Lack of motivation } & 1. No \\
\hline & & 2. Yes \\
\hline \multirow{2}{*}{11} & \multirow{2}{*}{ Communication with colleagues } & 1. No \\
\hline & & 2. Yes \\
\hline \multirow{2}{*}{12} & \multirow{2}{*}{ Cannot disconnect from work } & 1. No \\
\hline & & 2. Yes \\
\hline \multirow{2}{*}{13} & \multirow{2}{*}{ Space problems } & 1. No \\
\hline & & 2. Yes \\
\hline \multirow{2}{*}{14} & \multirow{2}{*}{ Interruptions } & 1. No \\
\hline & & 2. Yes \\
\hline \multirow{2}{*}{15} & \multirow{2}{*}{ Deficient internet connection } & 1. No \\
\hline & & 2. Yes \\
\hline
\end{tabular}

Source: Own elaboration.

Table A2. $t$-Test for equality of means on difficulties reported by the group analyzed according to whether they have an executive role or not, have children or not, live with a partner or not, and gender.

\begin{tabular}{ccccc}
\hline$p$-Value & Executive Role & Children & Sex & Living as a Couple \\
\hline Wrong postures & 0.1038 & 0.1866 & $2.25 \times 10^{-2 *}$ & 0.3531 \\
Social isolation & 0.9463 & $4.26 \times 10^{-2 *}$ & $6.69 \times 10^{-2}$ & $3.82 \times 10^{-3 * *}$ \\
Lack of motivation & 0.3622 & 0.3445 & 0.4576 & $9.35 \times 10^{-3 * *}$ \\
Communication with colleagues & 0.9463 & 0.9449 & $5.12 \times 10^{-2}$ & 0.1894 \\
Cannot disconnect from work & $1.34 \times 10^{-2 *}$ & $8.21 \times 10^{-2}$ & 0.8538 & 0.8639 \\
Space problems & 0.1043 & 0.8095 & $2.59 \times 10^{-2 *}$ & 0.5624 \\
Interruptions & 0.2531 & $7.05 \times 10^{-5 * * *}$ & 0.3905 & 0.2146 \\
\hline
\end{tabular}

Signif. codes: ${ }^{* * *} 0.001 ;{ }^{* *} 0.01 ;{ }^{*} 0.05 ; \cdot 0.1$. Source: Own elaboration.

\section{References}

1. Martínez Morán, P.C.; Diez Ruiz, F. Cinco Cambios en las Relaciones Laborales Provocadas por el Coronavirus. The Conversation. Available online: https:/ / theconversation.com/cinco-cambios-en-las-relaciones-laborales-provocados-por-el-coronavirus-14 2023 (accessed on 19 July 2020).

2. ILO. El Teletrabajo Durante la Pandemia de COVID-19 y Después de ella: Guía Práctica. Available online: https://www.ilo.org/ global/publications/WCMS_758007/lang--es/index.htm (accessed on 8 April 2021).

3. ILO. Observatorio de la OIT: La COVID-19 y el Mundo del Trabajo. Séptima Edición. Estimaciones Actualizadas y Análisis. Available online: https://www.ilo.org/wcmsp5/groups/public/---dgreports/---dcomm/documents/briefingnote/wcms_76 7045.pdf (accessed on 29 March 2021).

4. Anghel, B.; Cozzolino, M.; Lacuesta, A. El teletrabajo en España. Boletín Económico 2020, 2, 1-20.

5. Eurostat. Employed Persons Working from Home as a Percentage of the Total Employment, by Sex, Age, and Professional Status (\%). Available online: http:/ / appsso.eurostat.ec.europa.eu/nui/submitViewTableAction.do (accessed on 29 April 2021).

6. Bangemann, I. Europa y la Sociedad de la Información Planetaria; Recomendaciones al Consejo Europeo: Bruselas, Belgium, 1994.

7. Acuerdo Marco Europeo Sobre Teletrabajo, Brussels, Belgium. 2002. Available online: https://www.uned.ac.cr/viplan/images/ acuerdo-marco-europeo-sobre-teletrabajo.pdf (accessed on 1 August 2021).

8. Eraso, A.G.B. Teletrabajo en España: Acuerdo marco y Administración Pública. RIO Rev. Int. Organ. 2008, 1, $129-148$. 
9. Peiró, J.M.; Soler, A. El Impulso al Teletrabajo Durante el COVID-19 y los Retos Que Plantea, IvieLab. 2020. Available online: https:/ / www.ivie.es/wp-content/uploads/2020/05/11.Covid19IvieExpress.El-impulso-al-teletrabajo-durante-el-COVID19-y-los-retos-que-plantea.pdf (accessed on 1 August 2021).

10. Poquet, R. Balance de un Año de Teletrabajo en España. The Conversation. Available online: https://theconversation.com/ balance-de-un-ano-de-teletrabajo-en-espana-153864 (accessed on 14 March 2021).

11. Sebastián, R. Teletrabajo en España: De Dónde Venimos y a Dónde Vamos. Esade. Available online: https://dobetter.esade.edu/ es/teletrabajo-espana?_wrapper_format=html (accessed on 3 December 2020).

12. Real Decreto Legislativo 2/2015, de 23 de Octubre, Por el Que se Aprueba el Texto Refundido de la Ley del Estatuto de los Trabajadores; BOE: Madrid, Spain, 2015.

13. Real Decreto-Ley 28/2020, de 22 de Septiembre, de Trabajo a Distancia; BOE: Madrid, Spain, 2000.

14. Rastrollo, J.J. Deben de Tener Derecho a Teletrabajar los Empleados Públicos? The Conversation. Available online: https: / / theconversation.com/deben-tener-derecho-a-teletrabajar-los-empleados-publicos-145660 (accessed on 12 June 2020).

15. Ministerio de Política Territorial y Función Pública. Boletín Estadístico del Personal al Servicio de las Administraciones Públicas, Ministerio de Política Territorial y Función Pública. 2020. Available online: https:/ /www.hacienda.gob.es/CDI/Empleo_Publico/ Boletin_rcp/bol_semestral_201901_completo.pdf (accessed on 1 August 2021).

16. Ministerio de Política Territorial y Función Pública. Available online: https://www.mptfp.gob.es/dam/es/portal/ funcionpublica/secretaria-general-funcion-publica/Actualidad/2020/06/2020-06-17/Resolucion.pdf (accessed on 17 June 2020).

17. Bermúdez, A.P.; Fuentes, P.N. El futuro del trabajo en la Administración Pública: ¿Estamos preparados? Pertsonak Antolakunde Publikoak Kudeatzeko Euskal Aldizka. Rev. Vasca Gestión Pers. Organ. Públicas 2019, 3, 34-51.

18. BOE. Real Decreto Legislativo 5/2015, de 30 de Octubre, Por el Que se Aprueba el Texto Refundido de la Ley del Estatuto Básico del Empleado Público; BOE: Madrid, Spain, 2015.

19. Real Decreto 364/1995, de 10 de Marzo, por el que se Aprueba el Reglamento General de Ingreso del Personal al Servicio de la Administración general del Estado y de Provisión de Puestos de Trabajo y Promoción Profesional de los Funcionarios Civiles de la Administración General del Estado; BOE: Madrid, Spain, 1995.

20. Orden APU/3902/2005, de 15 de Diciembre, Por la Que se Dispone la Publicación del Acuerdo de la Mesa General de Negociación Por el Que se Establecen Medidas Retributivas y Para la Mejora de las Condiciones de Trabajo y la Profesionalización de los Empleados Públicos; BOE: Madrid, Spain, 2005.

21. Orden APU/1981/2006, de 21 de Junio, Por la Que se Promueve la Implantación de Programas Piloto de Teletrabajo en los Departamentos Ministeriales; BOE: Madrid, Spain, 2006.

22. González Bermejo, A. El Teletrabajo Como Nuevo Método en el Empleo Público: Propuesta de Plan Piloto. Ph.D. Thesis, Universitat Politècnica de València, Valencia, Spain, 2017.

23. Morón, M.S. El empleo público en España: Problemas actuales y retos de futuro. Rev. Aragón. Adm. Pública 2011, $13,19-27$.

24. Thibault, J. El Teletrabajo. In Análisis Jurídico Laboral; CES: Madrid, Spain, 2000.

25. Chaparro, F.O.; Morán, J.M. El Teletrabajo: Una Nueva Sociedad Laboral en la era de la Tecnología; McGraw-Hill: New York, NY, USA, 1997.

26. Barrios, R.S. El teletrabajo. Derecho PUCP 2007, 60, 325-350.

27. Davenport, T.H.; Pearlson, K. Two cheers for the virtual office. MIT Sloan Manag. Rev. 1998, $39,51$.

28. Gaeta, L. Teletrabajo y derecho: La experiencia italiana. Doc. Labor. 1996, 49, 33-56.

29. Huws, U.; Robinson, W.B.; Robinson, S. Telework towards the Elusive Office; John Wiley \& Sons, Inc.: Hoboken, NJ, USA, 1990.

30. Thibault, J. Teletrabajo y ordenación del tiempo de trabajo. In Proceedings of the JIS'2000: III Jornadas Sobre Informática y Sociedad, Madrid, Spain, 30 March-1 April 2001; pp. 233-250.

31. Bravo, O. Teletrabajo del lugar al que voy a las tareas que realizo. Debates IESA 2001, 16, 2.

32. Pérez, M.P.; Sánchez, A.M.; de Luis Carnicer, M.P.; Jiménez, M.J.V. La adopción del teletrabajo y las tecnologías de la información: Estudio de relaciones y efectos organizativos. Rev. Econ. Empresa 2004, 22, 11-28.

33. Caamaño Rojo, E. El teletrabajo como una alternativa para promover y facilitar la conciliación de responsabilidades laborales y familiares. Rev. Derecho 2010, 35, 79-105. [CrossRef]

34. Mokhtarian, P.L.; Salomon, I. Modeling the desire to telecommute: The importance of attitudinal factors in behavioral models. Transp. Res. Part A Policy Pract. 1997, 31, 35-50. [CrossRef]

35. Aderaldo, I.L.; Aderaldo, C.V.L.; Lima, A.C. Aspectos críticos do teletrabalho em uma companhia multinacional. Cad. EBAPE Br. 2017, 15, 511-533. [CrossRef]

36. Nilles, J.M. Traffic reduction by telecommuting: A status review and selected bibliography. Transp. Res. Part A Gen. 1988, 22, 301-317. [CrossRef]

37. Beňo, M. The Advantages and Disadvantages of E-working: An Examination using an ALDINE Analysis. Emerg. Sci. J. 2021, 5, 11-20. [CrossRef]

38. Ipsen, C.; van Veldhoven, M.; Kirchner, K.; Hansen, J.P. Six Key Advantages and Disadvantages of Working from Home in Europe during COVID-19. Int. J. Environ. Res. Public Health 2021, 18, 1826. [CrossRef]

39. Mokhtarian, P.L.; Bagley, M.N.; Salomon, I. The impact of gender, occupation, and presence of children on telecommuting motivations and constraints. J. Am. Soc. Inf. Sci. 1998, 49, 1115-1134. [CrossRef]

40. Boys, J. Megatrends: Working from Home: What's Driving the Rise in Remote Working? 2020. Available online: https: //www.cipd.co.uk/Images/working-from-home-1_tcm18-74230.pdf (accessed on 1 August 2021). 
41. Holgersen, H.; Jia, Z.; Svenkerud, S. Who and how many can work from home? Evidence from task descriptions. J. Labour Mark. Res. 2021, 55, 1-13.

42. Adams-Prassl, A.; Boneva, T.; Golin, M.; Rauh, C. Inequality in the impact of the coronavirus shock: Evidence from real time surveys. J. Public Econ. 2020, 189, 104245. [CrossRef]

43. Belzunegui-Eraso, A.; Erro-Garcés, A. Teleworking in the Context of the COVID-19 Crisis. Sustainability 2020, 12, 3662. [CrossRef]

44. Mas, A.; Pallais, A. Valuing alternative work arrangements. Am. Econ. Rev. 2017, 107, 3722-3759. [CrossRef]

45. Troup, C.; Rose, J. Working from home: Do formal or informal telework arrangements provide better work-family outcomes? Community Work. Fam. 2012, 15, 471-486. [CrossRef]

46. Caillier, J.G. The impact of teleworking on work motivation in a US federal government agency. Am. Rev. Public Adm. 2012, 42, 461-480. [CrossRef]

47. de Vries, H.; Tummers, L.; Bekkers, V. The benefits of teleworking in the public sector: Reality or rhetoric? Rev. Public Pers. Adm. 2019, 39, 570-593. [CrossRef]

48. Goldin, C. A grand gender convergence: Its last chapter. Am. Econ. Rev. 2014, 104, 1091-1119. [CrossRef]

49. Ishizuka, P.; Musick, K. Occupational Characteristics and Women's Employment during the Transition to Parenthood. Demography 2021, 58, 1249-1274. [CrossRef]

50. Gornick, J.C.; Meyers, M.K. Families That Work: Policies for Reconciling Parenthood and Employment; Russell Sage Foundation: New York, NY, USA, 2003.

51. Pettit, B.; Hook, J.L. Gendered Tradeoffs: Women, Family, and Workplace Inequality in Twenty-One Countries; Russell Sage Foundation: New York, NY, USA, 2009.

52. Barros, A.M.; Silva, J.R.G.D. Percepções dos indivíduos sobre as consequências do teletrabalho na configuração home-office: Estudo de caso na Shell Brasil. Cad. EBAPE Br. 2010, 8, 71-91. [CrossRef]

53. da Costa, I.D.S.A. Control in contemporary work arrangements: Teleworkers and the enterprise of the self'discourse/Controle em novas formas de trabalho: Teletrabalhadores e o discurso do empreendedorismo de si. Cad. EBAPE Br. 2013, 11, $462-475$.

54. Nohara, J.J.; Acevedo, C.R.; Ribeiro, A.F.; da Silva, M.M. O teletrabalho na percepção dos teletrabalhadores. INMR-Innov. Manag. Rev. 2010, 7, 150-170.

55. Gálvez, A.; Tirado, F.; Alcaraz, J.M. “Oh! Teleworking!” Regimes of engagement and the lived experience of female Spanish teleworkers. Bus. Ethics A Eur. Rev. 2020, 29, 180-192. [CrossRef]

56. Dockery, A.M.; Bawa, S. Is working from home good work or bad work? Evidence from Australian employees. Aust. J. Labour Econ. 2014, 17, 163-190.

57. Sánchez, C.P.; Mozo, A.M.G. Teletrabajo y vida cotidiana: Ventajas y dificultades para la conciliación de la vida laboral, personal y familiar [Telework and daily life: Its pros and cons for work-life balance]. Athenea Digit. 2009, 15, 57-79.

58. Sánchez, C.P. El teletrabajo: ¿Más libertad o una nueva forma de esclavitud para los trabajadores? IDP. Rev. Internet Derecho Política 2010, 11, 24-33.

59. Bartol, X.; Ramos, R. COVID-19 y Mercado de Trabajo: Teletrabajo, Largas Jornadas y Salud Mental. Asociación Libre de Economía, 2020. Available online: https:/ / alde.es/blog/covid-19-y-mercado-de-trabajo-teletrabajolargas-jornadas-y-saludmental/ (accessed on 15 June 2020).

60. Olson, M.H.; Primps, S.B. Working at home with computers: Work and nonwork issues. J. Soc. Issues 1984, 40, 97-112. [CrossRef]

61. Eom, S.J.; Choi, N.; Sung, W. The use of smart work in government: Empirical analysis of Korean experiences. Gov. Inf. Q. 2016, 33, 562-571. [CrossRef]

62. Harpaz, I. Advantages and disadvantages of telecommuting for the individual, organization and society. Work Study 2002, 51, 74-80. [CrossRef]

63. Wilton, R.D.; Páez, A.; Scott, D.M. Why do you care what other people think? A qualitative investigation of social influence and telecommuting. Transp. Res. Part A Policy Pract. 2011, 45, 269-282. [CrossRef]

64. Pinto, A.; Muñoz, G. Teletrabajo: Productividad y bienestar en tiempos de crisis. Esc. Psicol. 2020, 2, 1-10.

65. Bailey, N.B.K.D.E.; Kurland, N.B. The advantages and challenges of working here, there, anywhere, and anytime. Organ. Dyn. 1999, 28, 53-68.

66. Filardi, F.; Castro, R.M.P.; Zanini, M.T.F. Advantages and disadvantages of teleworking in Brazilian public administration: Analysis of SERPRO and Federal Revenue experiences. Cad. EBAPE Br. 2020, 18, 28-46. [CrossRef]

67. Scott, D.M.; Dam, I.; Páez, A.; Wilton, R.D. Investigating the effects of social influence on the choice to telework. Environ. Plan. A 2012, 44, 1016-1031. [CrossRef]

68. Gaspar, M.A.; Bellini, C.G.P.; Donaire, D.; dos Santos, S.A.; Mello, Á.A.A. Teletrabalho no desenvolvimento de sistemas: Um estudo sobre o perfil dos teletrabalhadores do conhecimento. Rev. Ciências Adm. 2011, 17, 1029-1052.

69. Limón, E.Y. La situación actual y el futuro del teletrabajo en el Perú. Not. CIELO 2021, 1, 2.

70. Behrens, K.; Kichko, S.; Thisse, J.F. Working from Home: Too Much of a Good Thing? 2021. Available online: https:/ /www.cesifo. org/en/publikationen/2021/working-paper/working-home-too-much-good-thing (accessed on 16 March 2021).

71. Beltrán, A.R.P.; Bilous, A.; Flores, J.C.; Escobar, C.F.B. El impacto del teletrabajo y la administración de empresas. Recimundo Rev. Cient. Investig. Conoc. 2020, 4, 326-335. 
72. Barandiarán, A. El Correo. Available online: https://www.elcorreo.com/economia/negociaciones-implantar-teletrabajo-202104 19215316-nt.html?ref=https:\%2F\%2Fwww.elcorreo.com\%2Feconomia\%2Fnegociaciones-implantar-teletrabajo-20210419215316 -nt.html (accessed on 27 April 2021).

73. Equipos y Talento. Los Españoles se Gastaron 615 Euros en Equipamiento Para Teletrabajar. Available online: https: //www.elmundofinanciero.com/noticia/92853/empresas/los-espanoles-se-gastaron-615-euros-en-equipamiento-parateletrabajar-durante-la-pandemia.html (accessed on 16 March 2021).

74. Equipos y Talento. Teletrabajo: Incremento de los Gastos del Hogar. Available online: https://www.equiposytalento.com/ fotoretribucion/teletrabajo-incremento-de-los-gastos-del-hogar (accessed on 20 April 2021).

75. Aguado, D. ¿Cómo Analizar la Nueva Realidad del Teletrabajo?_IIC (uam.es). Available online: https://www.iic.uam.es/rr-hh/ como-analizar-realidad-del-teletrabajo/ (accessed on 27 April 2021).

76. Dos Santos Soares, A. Teletrabalho e comunicaçao em grandes CPDs. Rev. Adm. Empresas 1995, 35, 64-77. [CrossRef]

77. Tremblay, D.G. Organização e satisfação no contexto do teletrabalho. Rev. Adm. Empresas 2002, 42, 54-65. [CrossRef]

78. IEBS Business School. El Futuro del Teletrabajo en la Nueva Normalidad. 2021. Available online: https://www.masquenegocio. com/2020/12/07/futuro-teletrabajo-nueva-normalidad/ (accessed on 27 April 2021).

79. Baruch, Y. Teleworking: Benefits and pitfalls as perceived by professionals and managers. New Technol. Work. Employ. 2000, 15, 34-49. [CrossRef]

80. Vasic, M. Challenges of teleworking during the COVID-19 pandemic. Anal. Ekon. Fak. Subotici 2020, 56, 63-79. [CrossRef]

81. Ballard, M. Two Third of Employees in Pain Working from Home. HR Magazin. Available online: https://www.hrmagazine.co. $\mathrm{uk} /$ content/news/two-thirds-of-employees-in-pain-working-from-home (accessed on 12 May 2021).

82. Kumar, N. The Times Hub. Available online: https://thetimeshub.in/teleworking-avoiding-the-ailments-associated-with-badposture/3316/ (accessed on 12 May 2021).

83. Maurer, R. Neglecting Economics Safety for Teleworkers Can Be Costly. SHRM. 2021. Available online: https://www.shrm.org/ resourcesandtools/hr-topics/risk-management/pages/ergonomicssafetyforteleworkers.aspx (accessed on 27 April 2021).

84. Lodovici, M.S. The Impact of Teleworking and Digital Work on Workers and Society. Available online: https:/ /www.europarl. europa.eu/RegData/etudes/STUD/2021/662904/IPOL_STU(2021)662904_EN.pdf (accessed on 27 April 2021).

85. Kwon, M.; Jeon, S.H. Do Leadership Commitment and Performance-Oriented Culture Matter for Federal Teleworker Satisfaction With Telework Programs? Rev. Public Pers. Adm. 2020, 40, 36-55. [CrossRef]

86. Couto, B. Resultados de la Encuesta Sobre el Impacto del Teletrabajo en las Mujeres, Asociación de Mujeres en el Sector Público. 2020. Available online: mujeresenelsectorpublico.com (accessed on 27 April 2021).

87. Capolongo, S.; Rebecchi, A.; Buffoli, M.; Appolloni, L.; Signorelli, C.; Fara, G.M.; D'Alessandro, D. COVID-19 and cities: From urban health strategies to the pandemic challenge. A decalogue of public health opportunities. Acta Biomed. Atenei Parm. 2020, $91,13$.

88. Camerin, F. Open issues and opportunities to guarantee the "right to the 'healthy'city" in the post-Covid-19 European city. Contesti. Città Territ. Progett. 2020, 2, 149-162.

89. Fabris, L.M.F.; Camerin, F.; Semprebon, G.; Balzarotti, R.M. New Healthy Settlements Responding to Pandemic Outbreaks: Approaches from (and for) the Global City. Plan J. 2020, 5, 385-406.

90. Eric, C.; Laura, C.; Enrico, F.; Gianni, G.; Enrico, L.; Laura, P.M.; Sergio, V. Effects of Air Pollution on COVID-19 Related Mortality in Northern Italy; Fondazione Eni Enrico Mattei (FEEM): Milan, Italy, 2020.

91. Honey-Rosés, J.; Anguelovski, I.; Chireh, V.K.; Daher, C.; Konijnendijk van den Bosch, C.; Litt, J.S.; Nieuwenhuijsen, M.J. The impact of COVID-19 on public space: An early review of the emerging questions-design, perceptions and inequities. Cities Health 2020, 1-17. [CrossRef]

92. R Core Team. R: A Language and Environment for Statistical Computing; R Foundation for Statistical Computing: Vienna, Austria, 2013; Available online: http:/ / www.R-project.org/ (accessed on 27 April 2021).

93. Fox, J.; Weisberg, S. An \{R\} Companion to Applied Regression, 3rd ed.; Sage: Thousand Oaks, CA, USA, 2019; Available online: https://socialsciences.mcmaster.ca/jfox/Books/Companion/ (accessed on 27 April 2021).

94. Wickham, H.; François, R.; Henry, L.; Müller, K. dplyr: A Grammar of Data Manipulation; R Package Version 1.0.2. 2020. Available online: https: / /CRAN.R-project.org/package=dplyr (accessed on 27 April 2021).

95. Wickham, H. ggplot2: Elegant Graphics for Data Analysis; Springer: New York, NY, USA, 2016; ISBN 978-3-319-24277-4. Available online: https: / / ggplot2.tidyverse.org (accessed on 27 April 2021).

96. Wickham, H.; Bryan, J. readxl: Read Excel Files; R Package Version 1.3.1. 2019. Available online: https:/ /CRAN.R-project.org/ package=readxl (accessed on 27 April 2021).

97. Fox, J. RcmdrMisc: R Commander Miscellaneous Functions; R Package Version 2.7-1. 2020. Available online: https:/ /CRAN.Rproject.org / package=RcmdrMisc (accessed on 27 April 2021).

98. Comtois, D. Summarytools: Tools to Quickly and Neatly Summarize Data; R Package Version 0.9.9. 2021. Available online: https:/ /CRAN.R-project.org/package=summarytools (accessed on 27 April 2021).

99. Delacre, M.; Lakens, D.; Leys, C. Why psychologists should by default use Welch's t-test instead of Student's t-test. Int. Rev. Soc. Psychol. 2017, 30, 92-101. [CrossRef]

100. Newbold, P.; Carlson, W.L.; Thorne, B. Statistics for Business and Economics; Pearson: Boston, MA, USA, 2013. 